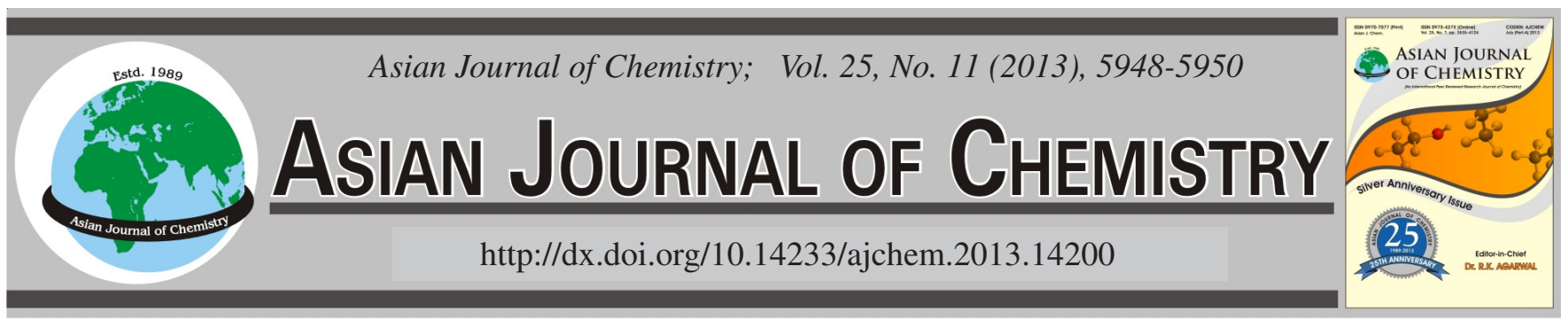

\title{
Synthesis and Anticonvulsant Evaluation of
}

(R)- and (S)-3-Carbobenzyloxy-amino-1-oxysuccinimides

Do-Hun LEE

Department of Chemistry, Dong-A University, Busan 604-714, Republic of Korea

Corresponding author: Fax: +82 51 2001053; E-mail: dohlee@dau.ac.kr

(Received: 18 June 2012;

Accepted: 22 April 2013)

AJC-13374

\begin{abstract}
A series of (R)-and (S)-3-carbobenzyloxy-amino-1-oxysuccinimides (5a-d) [(S)-3-carbobenzyloxy-amino-1-benzoyloxysuccinimde, (R)3-carbobenzyloxy-amino-1-acetyloxysuccinimde, (R)-3-carbobenzyloxy-amino-1,4-nitrobenzoyloxysuccinimde, (R)-3-carbobenzyloxyamino-1,4-fluorobenzoyloxysuccinimde] were synthesized and investigated their anticonvulsant activities in maximal electric shock seizure test and pentylenetetrazole induced seizure test.
\end{abstract}

Key Words: Amino-1-oxysuccinimides, Maximal electric shock seizure test, Pentylenetetrazole induced seizure test, Anticonvulsant activity.

ᄂ --------------

\section{INTRODUCTION}

Epilepsy is a common and diverse set of chronic neurological disorders characterized by seizures recent estimate indicate that $1 \%$ of population is affected some forms of epilepsy and that $20-40 \%$ of epileptic patients failed to experience significant seizure control with the drugs currently available $^{1-5}$. Futheremore, the antiepileptic drug presently used in clinical practics suffer from a broad range of adverse side effects including sedation, tetratogenecity, cognitive dulling and liver toxicity ${ }^{6-9}$. The clinically epilepsy consists of various forms of seizure, so that there is a need for combination and repeat therapy to control the such complex convulsion. Owing to this multitherapy, there is a danger of toxic and troublesome side effect. Consequently, there is a need for the development of new antiepileptic compound having broader clinical spectrum and lower toxic side effects. Recently, there has been many trials for the development of new typed anticonvulsant compounds including derivatives of various amino acid such as alanine derivatives and $\mathrm{N}$-benzoyl and $\mathrm{N}$-phenyl glycine amide and structural modification of currently used drug such as hydantoin, succinimdes and glutarimides and various GABA related compounds ${ }^{10-14}$.

But these compounds had some limitation in clinical use that some drug showed anticonvulsant effect only in maximal electric shock seizure test (MES) or pentylenetetrazole induced seizure test (PTZ). So we were interested in the development of new anticonvulsant compounds of broad spectrum. In connection with the studies for the development of anticonvulsants, we tried examining the structural similarities of currently available anticonvulsant compounds, known to act by different pharmacological mechanisms each other. From the studies of structural similarities of anticonvulsants, we find out the interesting facts that anticonvulsant compounds included the common structural moieties such as NH-CO-C-N and imide in their structures and also some MNDA antagonist, showing anticonvulsive effect, had structural similarity to aspartic acid, known as excitatory amino acid, in view of bioisoster. So we thought that the new anticonvulsants could be possibly developed from the aspartic acid in view of their structures. We designed the following imides such as A, having aforesaid common structures such as NH-CO-C-N, imide and aminocarbonyl of GABA in their structure originated from aspartic acid as shown in Fig. 1.<smiles>[R]N1C(=O)CC(NC(=O)OCc2ccccc2)C1=O</smiles>

Usually the stereoisomers exhibited different pharmacological activities, so we tried preparing all the (R)- and (S)compounds in order to investigate the pharmacological differences between their stereoisomers. The compounds (1a-d) could be prepared from the corresponding (R)-or (S)-aspartic acid in moderate yields by known chemical reactions as shown in Scheme-I. 


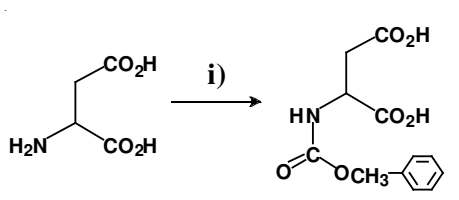

2

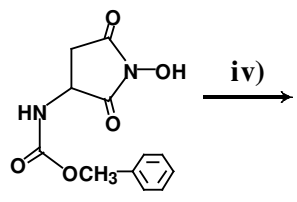

4

\section{i) $\mathrm{ClCOOCH}_{2} \mathrm{Ph}, \mathrm{NaOH}$} iii) $\mathrm{NH}_{2} \mathrm{OHHCl}, \mathrm{Na}_{2} \mathrm{CO}_{3}$

ii) $\mathrm{O}\left(\mathrm{COCH}_{3}\right)_{2}$ iv) $\mathrm{RCl}, \mathrm{Na}_{2} \mathrm{CO}_{3}$
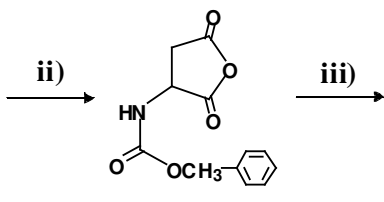

3
Scheme-I

\section{EXPERIMENTAL}

Melting points were determined on a Büchi 510 capillary melting point apparatus and uncorrected. Infrared spectra were recorded on a Perkin-Elmer 683 spectrophotometer. NMR spectra were recorded on a Varian XL-300 or Bruker AC 200 FT-NMR spectrometer in $\mathrm{CDCl}_{3}$ containing $\mathrm{Me}_{4} \mathrm{Si}$ as an internal reference. Mass spectra were obtained by using JEOL JMS DX 303 or HP 5892 mass spectrometer.

(R)-3-Carbobenzyloxy-amino-aspartic acid (2): To a solution of (R)-aspartic acid $1(5.20 \mathrm{~g}, 40 \mathrm{mmol})$ and $\mathrm{NaOH}$ ( $3.52 \mathrm{~g}, 88 \mathrm{mmol})$ in $\mathrm{H}_{2} \mathrm{O}(35 \mathrm{~mL})$ and acetone $(35 \mathrm{~mL})$ at 0 ${ }^{\circ} \mathrm{C}$ was added solution of carbobenzyloxy chloride (6.82 g, 40 $\mathrm{mmol})$ and $\mathrm{NaOH}(1.76 \mathrm{~g}, 44 \mathrm{mmol})$ in $\mathrm{H}_{2} \mathrm{O}(17 \mathrm{~mL})$ and acetone $(17 \mathrm{~mL})$. The reaction mixture was stirred at room temperature for $7 \mathrm{~h}$. After reaction solution was concentrated in vaccuo, it was carefully acidified $(\mathrm{pH}=2)$ with conc $\mathrm{HCl}$. Then the white solid was obtained in good yield $(8.20 \mathrm{~g}, 77$ $\%$ ). m.p. $115-116^{\circ} \mathrm{C} ; \mathrm{R}_{\mathrm{f}} 0.6$ (TLC eluent; benzene:THF:formic acid $=15: 5: 1, \mathrm{v} / \mathrm{v} / \mathrm{v})$; IR (neat, $v_{\max }, \mathrm{cm}^{-1}$ ): 3500, 3350, 3100, 1700, 1680; ${ }^{1} \mathrm{H}$ NMR (200 MHz, DMSO) $\delta 2.70(2 \mathrm{H}, \mathrm{m})$, $4.30(1 \mathrm{H}, \mathrm{m}), 5.16(2 \mathrm{H}, \mathrm{S}), 7.55(5 \mathrm{H}, \mathrm{m}), 12.64$ (1H, br) (S)3-carbobenzyloxy-amino-aspartic acid 2: yield $77 \%$; m.p. 115$116{ }^{\circ} \mathrm{C} ; \mathrm{R}_{\mathrm{f}} 0.6$ (TLC eluent; benzene; THF; formic acid = 15:5:1, v/v/v); the IR and ${ }^{1} \mathrm{H}$ NMR spectra of (R)-2 was identical with the IR and ${ }^{1} \mathrm{H}$ NMR spectra of (R)-2.

(R)-3-Carbobenzyloxy-amino-aspartic anhydride (3): A mixture of synthesized (R)-2 $10 \mathrm{~g}, 37 \mathrm{mmol}$ ) and acetic anhydride $(100 \mathrm{~mL})$ was stirred at room temperature for $2 \mathrm{~h}$. The reaction mixture was concentrated in vaccuo. After concentrating it was added diethyl ether $100 \mathrm{~mL}$. Then the white solid was obtained in good yield $(8.4 \mathrm{~g}, 91 \%)$ m.p. $134-135^{\circ} \mathrm{C} ; \mathrm{R}_{\mathrm{f}}$ 0.5 (TLC eluent; benzene:THF:formic acid = 15:5:1, v/v/v); IR (neat, $v_{\max }, \mathrm{cm}^{-1}$ ): 3370, 3350, 3110, 1710, 1500, 1220; ${ }^{1} \mathrm{H}$ NMR (200 MHz, DMSO) $\delta 2.50$ (2H, m), 2.99 (1H, m), 4.42 $(1 \mathrm{H}, \mathrm{S}), 5.05(2 \mathrm{H}, \mathrm{S}), 7.57(5 \mathrm{H}, \mathrm{m}), 10.82(1 \mathrm{H}, \mathrm{S})$.

(S)-3-Carbobenzyloxy-amino-aspartic anhydride (3): m.p. $95-96{ }^{\circ} \mathrm{C} ; \mathrm{R}_{\mathrm{f}} 0.8$ (TLC eluent; ethylacetate); the IR and ${ }^{1} \mathrm{H}$ NMR spectra of (S)-3 was identical with the IR and ${ }^{1} \mathrm{H}$ NMR spectra of (R)-3.

(R)-3-Carbobenzyloxy-amino-1-hydroxysuccinimde (4): A mixture of synthesized (R)-3-carbobenzyloxy-amino- aspartic anhydride $\mathbf{3}(2.49 \mathrm{~g}, 10 \mathrm{mmol})$ and hydroxylamine hydrochloride $(0.83 \mathrm{~g}, 12 \mathrm{mmol})$ in $\mathrm{H}_{2} \mathrm{O}(2 \mathrm{~mL})$ with $\mathrm{Na}_{2} \mathrm{CO}_{3}$ $(0.64 \mathrm{~g})$ was stirred at $0{ }^{\circ} \mathrm{C}$ for $1 \mathrm{~h}$. The reaction solution was concentrated in vaccuo. The white crystal $(1.45 \mathrm{~g}, 55 \%)$ was recrystallized by solution of ethanol and $\mathrm{H}_{2} \mathrm{O}$. Yield $55 \%$ m.p. ${ }^{\circ} \mathrm{C} ; \mathrm{R}_{\mathrm{f}} 0.5$ (TLC eluent; benzene: THF:formic acid = 15:5:1, v/v/v); IR (KBr, $\left.v_{\max }, \mathrm{cm}^{-1}\right): 3500,3370,3110,1710,1500$, 1220; ${ }^{1} \mathrm{H}$ NMR ( DMSO) $\delta 2.50$ (2H, m), 2.99 (1H, m), 4.42 $(1 \mathrm{H}, \mathrm{s}), 5.05(2 \mathrm{H}, \mathrm{s}), 7.67(5 \mathrm{H}, \mathrm{s}), 1082(1 \mathrm{H}, \mathrm{s})$.

(S)-3-Carbobenzyloxy-amino-1-hydroxy succinimde (4): yield $54 \%$ The IR and ${ }^{1} \mathrm{H}$ NMR spectra of (S)-4 were identical with the IR and ${ }^{1} \mathrm{H}$ NMR spectra of (R)-4.

Typical experimental procedure for synthesis of (R)-3carbobenzyloxy-amino-1-benzoyloxysuccinimde: A mixture of synthesized (R)-carbobenzyloxy-amino-1-hydroxysuccinimde (4) (0.56 g, $2 \mathrm{mmol})$ benzoylchloride $(0.34 \mathrm{~g}, 2 \mathrm{mmol})$ and $\mathrm{Na}_{2} \mathrm{CO}_{3}(0.25 \mathrm{~g})$ with acetone $8 \mathrm{~mL} \mathrm{H}_{2} \mathrm{O} 5 \mathrm{~mL}$ were stirred at room temperature for $5 \mathrm{~h}$. After EtOAc $(200 \mathrm{~mL})$ was added, the reaction mixture was added saturated $\mathrm{NaHCO}_{3}$ solution $(50 \mathrm{~mL}), 5 \% \mathrm{HCl}(50 \mathrm{~mL})$ and $\mathrm{H}_{2} \mathrm{O}(50 \mathrm{~mL})$ then the confined organic layers were concentrated in vaccuo. The obtained (R)3-carbobenzyloxy-amino-1- benzoyloxysuccinimide (5a) $(0.35 \mathrm{~g}, 46 \%)$ was recrystallized with EtOAc and $n$-hexane. m.p. $141-142{ }^{\circ} \mathrm{C} ; \mathrm{R}_{\mathrm{f}} 0.7$ (TLC eluent; EtOAc: $n$-hexane $=1: 1$, $\%)$; IR (KBr, $\left.v_{\max }, \mathrm{cm}^{-1}\right): 3410,3100,1950,1730,1690,1510$; ${ }^{1} \mathrm{H}$ NMR (DMSO) $\delta 2.85$ (2H, m), 4.77 (1H, s), 5.07 (2H, s), 7.77 (10H, m). (S)-3-Carbobenzyloxy-amino-1-benzoyloxysuccinimde (5a): yield $0.37 \mathrm{~g}(49 \%)$. The IR and ${ }^{1} \mathrm{H}$ NMR spectra of (S)-5a were identical with the IR and ${ }^{1} \mathrm{H}$ NMR spectra of (R)-5a.

(R)-3-Carbobenzyloxy-amino-1-acetyloxysuccinimde (5b): yield $56 \%$ m.p. $103-104{ }^{\circ} \mathrm{C} ; \mathrm{R}_{\mathrm{f}} 0.6$ (TLC eluent; EtOAc: $n$ hexane $=1: 1, \%)$; IR $\left(\mathrm{KBr}, v_{\max }, \mathrm{cm}^{-1}\right): 3380,3370,3100$, $3000,1720,1700,1510,1210 ;{ }^{1} \mathrm{H}$ NMR (DMSO) $\delta 2.33(3 \mathrm{H}$, s), $2.72(2 \mathrm{H}, \mathrm{m}), 4.64(1 \mathrm{H}, \mathrm{s}), 5.02(2 \mathrm{H}, \mathrm{s}), 7.71(5 \mathrm{H}, \mathrm{m})$.

(R)-3-Carbobenzyloxy-amino-1-4-nitrobenzoyloxysuccinimde (5c): yield $48 \%$; m.p. $175-176^{\circ} \mathrm{C} ; \mathrm{R}_{\mathrm{f}} 0.5$ (TLC eluent; EtOAc: $n$-hexane $=2: 1, \mathrm{v} / \mathrm{v}) ; \mathrm{IR}\left(\mathrm{KBr}, \mathrm{v}_{\max }, \mathrm{cm}^{-1}\right): 3400$, 3100, 3100, 3000, 1850, 1700, 1320, 1280; ${ }^{1} \mathrm{H}$ NMR (DMSO) $\delta 2.86(2 \mathrm{H}, \mathrm{m}), 2.72(2 \mathrm{H}, \mathrm{m}), 4.77(1 \mathrm{H}, \mathrm{s}), 5.08(2 \mathrm{H}, \mathrm{s}), 8.15$ $(10 \mathrm{H}, \mathrm{m})$.

(R)-3-Carbobenzyloxy-amino-1-4-fluorobenzoyloxysuccinimde (5d): yield $74 \%$; m.p. 176-177 ${ }^{\circ} \mathrm{C}$; $\mathrm{R}_{\mathrm{f}} 0.4$ (TLC eluent; EtOAc: $n$-hexane $=2: 1, \mathrm{v} / \mathrm{v}) ; \mathrm{IR}\left(\mathrm{KBr}, \mathrm{v}_{\max }, \mathrm{cm}^{-1}\right): 3400$, 3100, 3100, 3000, 1730, 1690, 1550, 1290, 1190; ${ }^{1} \mathrm{H}$ NMR (DMSO) $\delta 2.87(2 \mathrm{H}, \mathrm{m}), 4.77(1 \mathrm{H}, \mathrm{s}), 5.08(2 \mathrm{H}, \mathrm{s}), 7.80(10 \mathrm{H}$, $\mathrm{m})$. The IR and ${ }^{1} \mathrm{H}$ NMR spectra of (S)-5b (60\%), 5c (49\%), $5 \mathrm{~d}(67 \%)$ were identical with the IR and ${ }^{1} \mathrm{H}$ NMR spectra of (R)-5b, 5c and $5 d$.

\section{RESULTS AND DISCUSSION}

All products gave satisfactory spectral data. So the compounds 5a-d were submitted to the following anticonvulsant tests. It was reported that MES test was correlated to generalized tonic clonic seizure and PTZ test to generalized absence seizure. So these two kinds of seizure test are very meaningful for the clinical prediction of anticonvulsant drug candidates. Therefore we investigated the anticonvulsant activity for those compounds((R)-5a-d and (S)-5a-d) in maximal electric shock 
seizure test (MES test) and pentylenetetrazole induced seizure test (PTZ test). The results of anticonvulsant activity are summarized in Table- 1 .

\begin{tabular}{|c|c|c|c|}
\hline \multicolumn{4}{|c|}{$\begin{array}{l}\text { TABLE-1 } \\
\text { ONVULSANT EVALUATION OF } \\
\text { OBENZYLOXY-AMINO-1-3- } \\
\text { SUCCINIMDES IN MICE }\end{array}$} \\
\hline \multirow{2}{*}{ Compound } & \multirow{2}{*}{ Config } & \multicolumn{2}{|c|}{$\mathrm{ED}_{50}(\mathrm{mg} / \mathrm{Kg})^{\mathrm{a}}$} \\
\hline & & $\operatorname{MES}(\mathrm{P} 1)^{\mathrm{b}}$ & PTZ \\
\hline $5 \mathbf{a}$ & $\mathrm{R}$ & 97.2 & 103.2 \\
\hline $5 b$ & $\mathrm{R}$ & 172.5 & 137.5 \\
\hline $5 c$ & $\mathrm{R}$ & 98.3 & 81.3 \\
\hline $5 d$ & $\mathrm{R}$ & 125.2 & 100.0 \\
\hline $5 \mathbf{a}$ & S & 121.3 & 106.3 \\
\hline $5 b$ & S & 92.3 & 89.7 \\
\hline $5 c$ & $\mathrm{~S}$ & 90.6 & 112.3 \\
\hline $5 d$ & S & 102.2 & 97.2 \\
\hline Phenobarbital $^{\mathrm{d}}$ & - & $21.8(3.1)$ & $13.1(5.3)$ \\
\hline \multicolumn{4}{|c|}{ 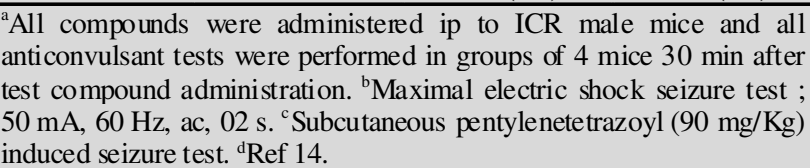 } \\
\hline
\end{tabular}

It is found that the (R)-isomer was more active than (S)isomer about the anticonvulsant activity. Especially, (R)- and (S)-5a-d were reported to be active in only PTZ. We continue to synthesize their analogs and evaluate their anticonvulsant activities in order to develop more active anticonvulsant compounds and define the structure-activity relationship more distinctly.

\section{REFERENCES}

1. (a) J.M. Liebmann and A. Schneider, Ann. Med. Chem., 20, 11 (1985); (b) E.A. Swinyard, Antiepilepic Drug, Ravan Press: New York, edn. 2, p. 5 (1982).

2. D. Schmidt, Epilepsia, 25, 244 (1984).
3. D. Lindhart and R.J.E.A. Hopperner, Epilepsia, 25, 77 (1984).

4. J.A. Vida, In ed.: W.O. Foye, Principle of Medicinal Chemistry, Lea \& Febiger: Philadelphia, Ch. 11 (1995).

5. (a) H. Kohn, K.N. Sawhney, D. LeGall and J.D. Leader, J. Med. Chem., 34, 2444 (1991); (b) H. Kohn, K.N. Sawhney, D. LeGall and J.D. Cinley, J. Med. Chem., 33, 919 (1990); (c) J.D. Conley and H. Kohn, J. Med. Chem., 30, 567 (1987).

6. (a) J. Takahashi, K. Ogui, H. Fujimura, I. Satoda, T. Fukui and Y. Yamamoto, Swiss Patent 393355, Oct. 30 (1965); (b) D.E. Thorne, US Patent. 3657341, April 8 (1972)

7. (a) W.J. Brouillette, V.P. Jestkov, M.L. Brown, M.S. Akhatar, T.M. DeLorey and G.B. Brown, J. Med. Chem., 37, 3289 (1994); (b) C.H. Kwon, M.T. Iqbal and J.N.D. Eurpel, J. Med. Chem., 34, 1845 (1991).

8. (a) V.A. Farrar, M. Ciechanowicz-Rutkowska, J. Grochowski, P. Serda, G. Filippini, C.N. Hinko, A. El-Assadi, J.A. Moore, I.O. Edafiogho, C.W. Andrew, M. Cory, J.M. Nicholson and K.R. Scott, J. Med. Chem., 36, 3517 (1993); (b) I.O. Edafiogho, K.R. Scitt, J.A. Moore, V.A. Farrar and J.M. Nicholson, J. Med. Chem., 34, 387 (1991); (c) M.R. Borenstein and P.H. Duukas, J. Pharm. Sci., 76, 300 (1987); (d) M.J. Kornet, J. Pharm. Sci., 73, 405 (1984).

9. (a) D.T. Witiak, S.K. Seth, E.R. Baizmann, S.L. Weibel and H.H. Wolf, J. Med. Chem., 19, 1419 (1976); (b) H.Y. Aboul-Eneine, C.W. Schauberger, A.R. Hansen and L.J. Fischer, J. Med. Chem., 18, 736 (1975).

10. (a) K.E. Andersen, C. Braestrup, F.C. Gronwald, A.S. Jorgensen, E.B. Nielsen, U. Sonnewald, P.O. Sorensen, P.D. Suzdak and L.J.S. Knutsen, J. Med. Chem., 36, 1716 (1993); (b) V. N'Goka, G. Schlewer, J.M. Linget, J.P. Chambon and C.G. Wermuth, J. Med. Chem., 34, 2547 (1991); (c) J.R. Bruke and R.B. Silvermann, J. Am. Chem. Soc., 113, 9329 (1991).

11. (a) P.C.K. Pook, D.E. Jane and J.C. Watkins, J. Med. Chem., 37, 4288 (1994); (b) R. Heckendorn, H. Allgeier, J. Baud, W. Grunzenhauser and C. Angst, J. Med. Chem., 36, 3721 (1993).

12. For the preparation of compound 4: M. Itoh, Chem. Pharm. Bull., 17, 1679 (1969); For the preparation of compounds 1 and 2: S.R. Sandler and W. Karo, Organic Functional Group Preparation; Academic Press: New York, Vol. 3, p. 253 (1972).

13. (a) E.A. Swinyard, J.H. Woodhead, H.S. White and M.R. Franklin, in ed: R. Levy, General Priciples, Experimental Section, Quantification and Evaluation of Anticonvulsants in Antiepileptic Drugs, Ravan Press, New York, edn. 3, p. 88 (1988); (b) R.L. Krall, J.K. Penry, B.G. White, H.J. Kupferberg and C.A. Swinyard, Epilepsia, 19, 409 (1978).

14. R.J. Porter, J.J. Cereghino, G.D. Gladding, B.J. Hessie, H.J. Kupferberg, B. Scoville and B.G. White, Cleveland Clin. Q., 51, 283 (1984). 